\title{
A 200 year sulfate record from 16 Antarctic ice cores and associations with Southern Ocean sea-ice extent
}

\author{
Daniel DIXON, Paul A. MAYEWSKI, Susan KASPARI, Karl KREUTZ, \\ Gordon HAMILTON, Kirk MAASCH, Sharon B. SNEED, Michael J. HANDLEY
}

\author{
Climate Change Institute, Department of Earth Sciences, University of Maine, 303 Bryand Global Sciences Center, \\ Orono, ME 04469-5790, USA \\ E-mail: daniel.dixon@maine.edu
}

\begin{abstract}
Chemistry data from 16, 50-115 m deep, sub-annually dated ice cores are used to investigate spatial and temporal concentration variability of sea-salt (ss) $\mathrm{SO}_{4}{ }^{2-}$ and excess (xs) $\mathrm{SO}_{4}{ }^{2-}$ over West Antarctica and the South Pole for the last 200 years. Low-elevation ice-core sites in western West Antarctica contain higher concentrations of $\mathrm{SO}_{4}{ }^{2-}$ as a result of cyclogenesis over the Ross Ice Shelf and proximity to the Ross Sea Polynya. Linear correlation analysis of 15 West Antarctic ice-core $\mathrm{SO}_{4}{ }^{2-}$ time series demonstrates that at several sites concentrations of $\mathrm{ssSO}_{4}{ }^{2-}$ are higher when sea-ice extent (SIE) is greater, and the inverse for $\mathrm{xsSO}_{4}{ }^{2-}$. Concentrations of $\mathrm{xsSO}_{4}{ }^{2-}$ from the South Pole site (East Antarctica) are associated with SIE from the Weddell region, and West Antarctic $\mathrm{xsSO}_{4}{ }^{2-}$ concentrations are associated with SIE from the Bellingshausen-Amundsen-Ross region. The only notable rise of the last 200 years in $\mathrm{xsSO}_{4}{ }^{2-}$, around 1940, is not related to SIE fluctuations and is most likely a result of increased $\mathrm{xsSO}_{4}{ }^{2-}$ production in the mid-low latitudes and/or an increase in transport efficiency from the mid-low latitudes to central West Antarctica. These high-resolution records show that the source types and source areas of $\mathrm{ssSO}_{4}{ }^{2-}$ and $\mathrm{xsSO}_{4}{ }^{2-}$ delivered to eastern and western West Antarctica and the South Pole differ from site to site but can best be resolved using records from spatial ice-core arrays such as the International Trans-Antarctic Scientific Expedition (ITASE).
\end{abstract}

\section{INTRODUCTION}

Reliable instrumental records of Earth's climate have only been collected since the late 19th century; of these, highresolution records of Southern Hemisphere climate are geographically sparse and rarely extend back more than 50 years. A longer perspective on climate variability can be obtained by studying natural archives that provide proxies for past climate, such as tree rings, sediment cores and ice cores.

Antarctic ice cores are a valuable resource for reconstructing the climate of the past because they can provide sub-annually resolved, continuous proxy records of atmospheric temperature, atmospheric circulation, precipitation, the El Niño-Southern Oscillation and sea-ice extent, among others (Jouzel and others, 1983; Mayewski and others, 1995, 2004; Cullather and others, 1996; Kreutz and others, 1997, 2000a; Meyerson and others, 2002). Furthermore, strong teleconnections link the continent to the mid- and low latitudes (Carleton, 1992), ensuring that records of Southern Hemisphere climate are captured in the chemistry of its snow and ice layers.

Sulfate $\left(\mathrm{SO}_{4}{ }^{2-}\right)$ is one of the major chemical species present in Earth's atmosphere, and its aerosols are involved in many important atmospheric processes. $\mathrm{SO}_{4}{ }^{2-}$ aerosols play a significant role in the heat budget of the global atmosphere, mainly through the scattering of incoming solar radiation and through indirect effects involving clouds (Charlson and others, 1990). $\mathrm{SO}_{4}{ }^{2-}$ from large explosive volcanic eruptions significantly affects stratospheric chemistry, inducing a higher catalytic destruction rate of ozone and resulting in enhanced levels of ultraviolet-B (UV-B) radiation at the Earth's surface (Berresheim and others, 1995).
The isolated Antarctic continent is an ideal place to study natural atmospheric $\mathrm{SO}_{4}{ }^{2-}$ variability, thanks to its remoteness from major anthropogenic $\mathrm{SO}_{4}{ }^{2-}$ sources that can confound the investigation of natural variability compared to more populated regions (Shaw, 1982; Legrand and Mayewski, 1997).

\section{Sulfate sources and transport pathways}

Sea-salt (ss) $\mathrm{SO}_{4}{ }^{2-}$ reaches West Antarctica almost exclusively through the lower troposphere, and as a result can contribute over $25 \%$ of the total $\mathrm{SO}_{4}{ }^{2-}$ budget to coastal and low-elevation sites (Dixon and others, 2004). Interpreting the significance of excess (xs) $\mathrm{SO}_{4}{ }^{2-}$ concentrations in Antarctica is complicated because the $\mathrm{xsSO}_{4}{ }^{2-}$ arrives from a variety of sources. The major source is biogenic $\mathrm{xsSO}_{4}{ }^{2-}$ that results from vigorous biological activity in the surrounding oceans during the Southern Hemisphere summer months (Bates and others, 1992; Legrand and Mayewski, 1997). The strong seasonality of biogenic $\mathrm{xsSO}_{4}{ }^{2-}$ production and transport results in well-defined annual peaks in all of the ice-core records used in this study (Dixon and others, 2004). Biogenic source $\mathrm{xsSO}_{4}{ }^{2-}$ reaches a peak from November to January (Minikin and others, 1998) and arrives in West Antarctica via two major transport pathways. Biogenic $\mathrm{xsSO}_{4}{ }^{2-}$, produced south of $60^{\circ} \mathrm{S}$ (Minikin and others, 1998), is transported mainly through the lower troposphere, whereas biogenic $\mathrm{xSSO}_{4}{ }^{2-}$, primarily from low-mid-latitude sources, is transported through the mid-upper troposphere (Shaw, 1982; Legrand and others, 1992; Minikin and others, 1998). The $\mathrm{SsSO}_{4}{ }^{2-}$ fraction reaches a peak during the winter/spring transition, when intense cyclonic activity and intrusions of lower-tropospheric marine air masses are common (Legrand and others, 1992; Whitlow and others, 1992; Hogan, 1997). 


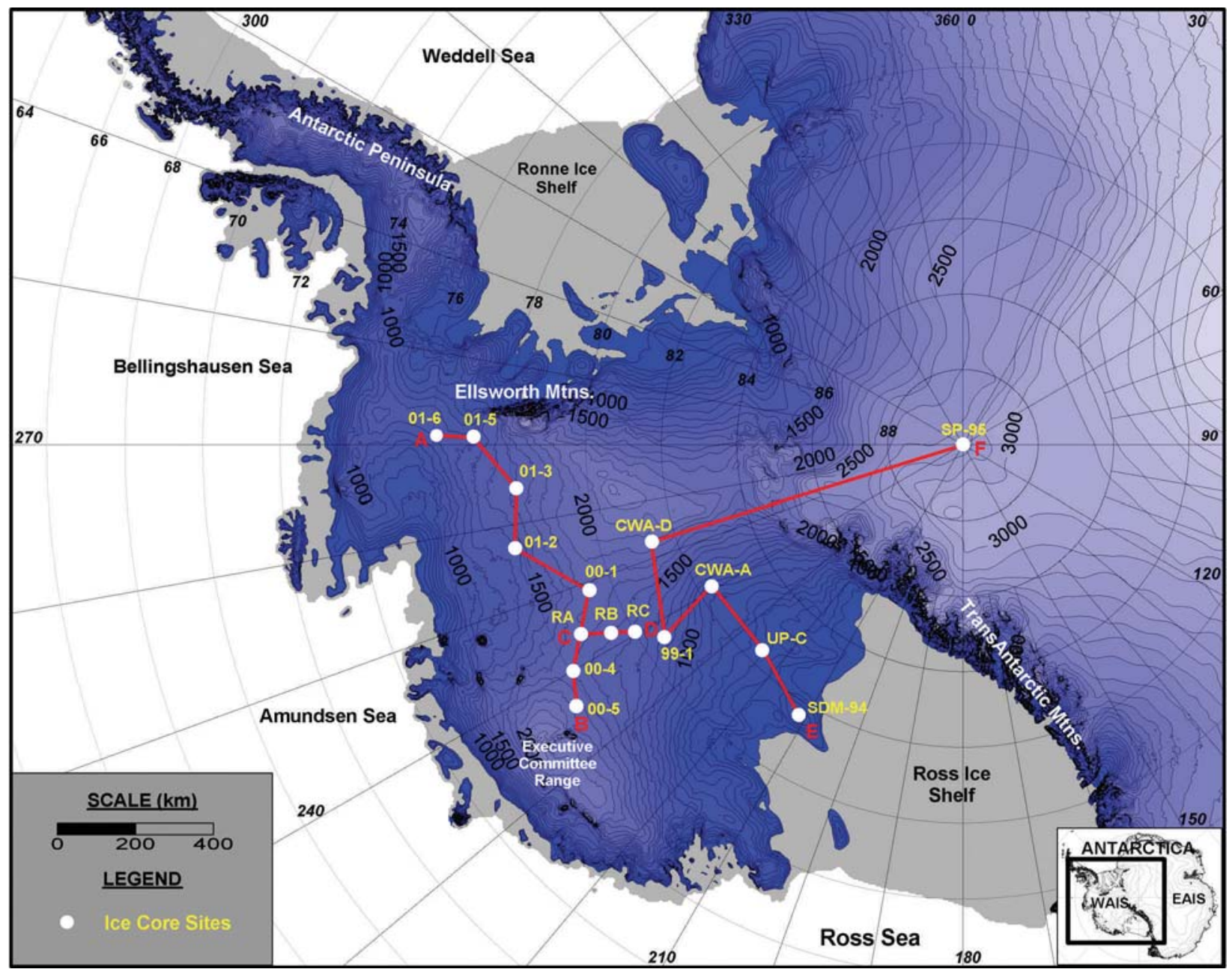

Fig. 1. Location map of sites for all ice cores used in this study. RA, RB and RC represent core sites RIDS-A, RIDS-B and RIDS-C, respectively. Red lines (A-B, C-D and E-F) are transects referred to in Figure 2. Map created using the RADARSAT-1 Antarctic Mapping Project (RAMP) digital elevation model (Liu and others, 2001).

Other important sources of West Antarctic $\mathrm{xsSO}_{4}{ }^{2-}$ are volcanic eruptions and the multiple-source stratospheric $\mathrm{SO}_{4}{ }^{2-}$ layer that is comprised of background volcanic, biogenic and potentially anthropogenic contributions. Volcanic $\mathrm{xsSO}_{4}{ }^{2-}$ input to West Antarctica from large explosive eruptions is episodic. The major transport pathway for this source of $\mathrm{xsSO}_{4}{ }^{2-}$ is the mid-upper troposphere and stratosphere (Legrand and Delmas, 1987; Dibb and Whitlow, 1996; Legrand and Wagenbach, 1999). The stratospheric contribution of $\mathrm{SO}_{4}{ }^{2-}$ is generally assumed to be minimal (Legrand, 1997; Bergin and others, 1998) except after large explosive volcanic eruptions (Legrand and Delmas, 1987; Dibb and Whitlow, 1996). Volcanic $\mathrm{xsSO}_{4}{ }^{2-}$ from small volcanic eruptions may travel through the lower troposphere but usually does not travel far from the eruption source.

The influence of lower-tropospheric air masses diminishes with increasing elevation and distance from the coast, causing $\mathrm{SsSO}_{4}{ }^{2-}$ concentrations to decrease concurrently. The influence of mid-upper tropospheric and stratospheric air masses on coastal sites is minor (Minikin and others, 1998; Legrand and Wagenbach, 1999) compared to higherelevation interior areas. As a result, large explosive volcanic eruptions are most clearly distinguished in ice-core $\mathrm{xsSO}_{4}{ }^{2-}$ records from higher-elevation interior areas.

Polynyas are an important local source of $\mathrm{ssSO}_{4}{ }^{2-}$ and $\mathrm{xSSO}_{4}{ }^{2-}$ in coastal Antarctic precipitation. Although relatively small in area, coastal polynyas are areas of considerable sea-ice production and salt flux in winter, and regions of greatly enhanced primary and secondary production in summer (Arrigo and Van Dijken, 2003; Kaspari and others, 2005). The largest polynya in the Southern Ocean is the Ross Sea Polynya, which is one of the most biologically productive regions around Antarctica (Arrigo and others, 1998). It forms annually as a result of the strong katabatic winds flowing off the Ross Ice Shelf into the southwestern Ross Sea (Bromwich and others, 1992).

Traditionally, bubble bursting at the open-ocean water surface was considered to be the sole source of sea-salt aerosols in Antarctic precipitation, but more recently Southern Ocean sea-ice extent (SIE) has been shown to play an important role in controlling concentrations of $\mathrm{ssSO}_{4}{ }^{2-}$ in coastal Antarctic precipitation through the formation of highly saline frost flowers on the surface of new sea ice (Wagenbach and others, 1998; Rankin and others, 2000, 2002). Highly saline brine forms at the surface of new sea ice, and below $-8^{\circ} \mathrm{C}$ sodium sulfate decahydrate (mirabilite: $\mathrm{Na}_{2} \mathrm{SO}_{4} 10 \mathrm{H}_{2} \mathrm{O}$ ) precipitates from the brine (Richardson, 1976). This process produces aerosols strongly depleted in $\mathrm{SO}_{4}{ }^{2-}$ relative to $\mathrm{Na}^{+}$from the brine (Rankin and others, 2002). Several studies report negative winter $\mathrm{xsSO}_{4}{ }^{2-}$ values from aerosol, snow and ice-core samples at coastal sites (Mulvaney and Peel, 1988; Wagenbach and others, 1998), 
Table 1. Information for each ice core used in this study

\begin{tabular}{|c|c|c|c|c|c|c|c|c|c|c|c|c|}
\hline \multirow[t]{2}{*}{ Location } & Lat. & Long. & Elev. & Mean acc. & $\begin{array}{l}\text { Distance } \\
\text { from } \\
\text { open } \\
\text { water }\end{array}$ & $\begin{array}{l}\mathrm{SsSO}_{4} \\
\text { conc. } \\
(1952-91 \\
\text { mean) }\end{array}$ & $\begin{array}{l}\mathrm{xsSO}_{4} \\
\text { conc. } \\
(1952-91 \\
\text { mean) }\end{array}$ & $\begin{array}{l}\mathrm{SsSO}_{4}: \\
\mathrm{xsSO}_{4} \\
(1952-91 \\
\text { mean })\end{array}$ & Depth & $\begin{array}{l}\text { High-res. } \\
\text { time period }\end{array}$ & $\begin{array}{l}\text { Sampling } \\
\text { resolution }\end{array}$ & \multirow[t]{2}{*}{$\begin{array}{l}\text { Samples } \\
\mathrm{a}^{-1} \text { (high- } \\
\text { res. mean) }\end{array}$} \\
\hline & ${ }^{\circ} \mathrm{S}$ & ${ }^{\circ} \mathrm{W}$ & $\mathrm{m}$ & cm w.e. $a^{-1}$ & $\mathrm{~km}$ & $\mathrm{ppb}$ & $\mathrm{ppb}$ & ppb & $\mathrm{m}$ & years $A D$ & $\mathrm{~cm}$ & \\
\hline ITASE 01-6 & 76.0968 & 89.0147 & 1232 & 39.7 & 320 & 7.1 & 29.9 & 0.24 & 18 & 2000-1978 & $2.1-3.6$ & 28 \\
\hline ITASE 01-3 & 78.1202 & 95.6463 & 1633 & 2.7 & 370 & 4.2 & 24.9 & 0.17 & 71 & 2002-1859 & $1.5-3.2$ & 20 \\
\hline ITASE 01-2 & 77.8436 & 102.9103 & 1353 & 2.5 & 295 & 6.4 & 30.8 & 0.21 & 71 & $2002-1890$ & $1.7-4.1$ & 27 \\
\hline ITASE 00-1 & 79.3831 & 111.2286 & 1791 & 2.3 & 475 & 5.7 & 30.0 & 0.19 & 105 & 2001-1651 & $1.6-3.5$ & 13 \\
\hline ITASE 00-4 & 78.0829 & 120.0764 & 1697 & 9 & 460 & 7.9 & 37.2 & 0.21 & 58 & 2001-1799 & $1.4-3.1$ & 13 \\
\hline ITASE 00-5 & 77.6821 & 123.9914 & 1828 & 4.6 & 400 & 8.1 & 53.7 & 0.15 & 60 & 2001-1708 & $2-6.4$ & 8 \\
\hline RIDS-A & 78.7300 & 116.3300 & 1740 & 3.6 & 440 & 6.2 & 28.0 & 0.22 & 150 & 1996-1831 & $3 \& 60$ & 11 \\
\hline RIDS-B & 79.4600 & 118.0500 & 1603 & 4.8 & 535 & 5.9 & 39.1 & 0.15 & 60 & 1996-1926 & $3,20, \& 30$ & 9 \\
\hline RIDS-C & 80.0100 & 119.5600 & 1530 & 1.1 & 580 & 5.8 & 45.7 & 0.13 & 60 & 1996-1905 & $2,3, \& 25$ & 9 \\
\hline CWA-(A) & 82.3671 & 119.2855 & 950 & 4.5 & 850 & 13.1 & 46.1 & 0.28 & 93.5 & 1994-1939 & $3 \& 40$ & 9 \\
\hline ITASE 99-1 & 80.6200 & 122.6300 & 1350 & 3.6 & 640 & 11.8 & 40.3 & 0.29 & 58 & $2000-1713$ & $2-4.3$ & 8 \\
\hline CWA-(D) & 81.3723 & 107.2750 & 1930 & 1.3 & 735 & 5.5 & 30.3 & 0.18 & 50.5 & 1994-1952 & $3 \& 60$ & 13 \\
\hline South Pole-95 & 90.0000 & 0.0000 & 2850 & 8.2 & 1300 & 2.6 & 52.6 & 0.05 & 71 & $1992-1487$ & 2 & 6 \\
\hline
\end{tabular}

indicating that the brine associated with frost flowers is a dominant source of marine aerosols to coastal sites in winter. However, Kreutz and others (2000b), using the Siple Dome ice core, and Kaspari and others (2005), using International Trans-Antarctic Scientific Expedition (ITASE) cores, show that the ice-core sea-salt record is a proxy for the strength and position of the Amundsen Sea low, indicating that wind strength is still a major control of seasalt aerosols in Antarctic precipitation whether the aerosols are derived from frost flowers or the open-ocean surface.

$\mathrm{SIE}$ is also linked to concentrations of $\mathrm{xSSO}_{4}{ }^{2-}$ in the Antarctic atmosphere (Welch and others, 1993; Peel and others, 1996; Meyerson and others, 2002; Curran and others, 2003) via its strong, consistent association with the methanesulfonate (MS) seasonal cycle of marine productivity (Minikin and others, 1998). Peel and others (1996) show that in areas adjacent to the Weddell Sea, extensive sea-ice cover appears to suppress emissions of the $\mathrm{xsSO}_{4}{ }^{2-}$ precursor dimethylsulfide (DMS). However, other studies reveal a positive relationship between increased MS at coastal sites and increased SIE in adjacent longitudinal ocean sectors (Welch and others, 1993; Curran and others, 2003). Meyerson and others (2002) note a positive relationship between South Pole MS concentrations and AmundsenRoss region SIE.

In this study, chemistry data from 16, 50-115 m deep, sub-annually dated ice-core records (Fig. 1) are used to investigate recent spatial and temporal concentration variability of the soluble $\mathrm{ssSO}_{4}{ }^{2-}$ and $\mathrm{xsSO}_{4}{ }^{2-}$ in ice cores over West Antarctica. We investigate associations between the $\mathrm{xsSO}_{4}{ }^{2-}$ and $\mathrm{ssSO}_{4}{ }^{2-}$ concentration time series from each core and SIE and we discuss the importance of the SIE- $-\mathrm{SO}_{4}{ }^{2-}$ correlations in terms of the 1940 background $\mathrm{xsSO}_{4}{ }^{2-}$ rise observed in our previous study (Dixon and others, 2004).

\section{METHODOLOGY}

The ice cores used in this study were collected during Antarctic field seasons 1994-2001. The eight older cores (SP-95, SDM-94, RIDS-A, -B and -C, CWA-A and -D and
Up-C) were sectioned using the ultra-clean procedures described in Buck and others (1992). The eight new US ITASE cores were sampled at high resolution using the University of Maine melter system (up to 50 samples $\mathrm{m}^{-1}$; Table 1) to develop sub-annually resolved time series (Dixon and others, 2004). To prevent contamination, only the inner portion of each core was sampled, and, prior to melting, the ends of each core section were scraped using a sterile surgical stainless-steel blade. Each sample was analyzed for its soluble major-ion content $\left(\mathrm{Na}^{+}, \mathrm{K}^{+}, \mathrm{Mg}^{2+}\right.$, $\mathrm{Ca}^{2+}, \mathrm{Cl}^{-}, \mathrm{NO}_{3}{ }^{-}, \mathrm{SO}_{4}{ }^{2-}$ ) using a Dionex ${ }^{\circledR} \mathrm{DX}-500$ ion chromatograph coupled to a Gilson ${ }^{\circledR}$ autosampler, and concentrations are reported in $\mu \mathrm{g} \mathrm{L}^{-1}$ (ppb). To determine anion $\left(\mathrm{Cl}^{-}, \mathrm{SO}_{4}{ }^{2-}\right.$ and $\left.\mathrm{NO}_{3}{ }^{-}\right)$concentrations, the chromatograph was set up with an AS-11 column with $6 \mathrm{mM} \mathrm{NaOH}$ eluent. For cation $\left(\mathrm{Na}^{+}, \mathrm{Ca}^{2+}, \mathrm{Mg}^{2+}\right.$ and $\left.\mathrm{K}^{+}\right)$concentrations, a CS-12a column with $25 \mathrm{mM}$ MSA eluent was used. All ion concentrations are determined with an accuracy of better than $0.1 \mathrm{ppb}$.

The high-resolution section of every ice core is dated by matching seasonal peaks from each of the major-ion time series in accord with seasonal timing identified by previous research (e.g. Whitlow and others, 1992; Wagenbach, 1996; Legrand and Mayewski, 1997; Kreutz and Mayewski, 1999; Dixon and others, 2004). The counting of annual peaks between known large explosive volcanic events in our ion records, such as the 1815 eruption of Tambora, Indonesia, the 1883 eruption of Krakatau, Indonesia, the 1963 eruption of Agung, Indonesia, and the 1991 eruption of Pinatubo, Philippines, confirms that each year is preserved in each high-resolution ice-core record and allows a dating accuracy of better than 1 year (Dixon and others, 2004).

Each ice-core $\mathrm{SO}_{4}{ }^{2-}$ time series is separated into its primary constituents, $\mathrm{ssSO}_{4}{ }^{2-}$ and $\mathrm{xsSO}_{4}{ }^{2-}$, using the technique described by $\mathrm{O}^{\prime}$ Brien and others (1995). The $\mathrm{ssSO}_{4}{ }^{2-}$ fraction is calculated by applying a standard sea-water ratio of $30.61\left(\mathrm{Na}^{+}\right), 1.1\left(\mathrm{~K}^{+}\right), 3.69\left(\mathrm{Mg}^{2+}\right), 1.16\left(\mathrm{Ca}^{2+}\right), 55.04\left(\mathrm{Cl}^{-}\right)$ and $7.68\left(\mathrm{SO}_{4}{ }^{2-}\right)$ to the ion concentrations in each sample (Holland, 1978). The concentration values are reduced incrementally according to this ratio until a value of zero is 


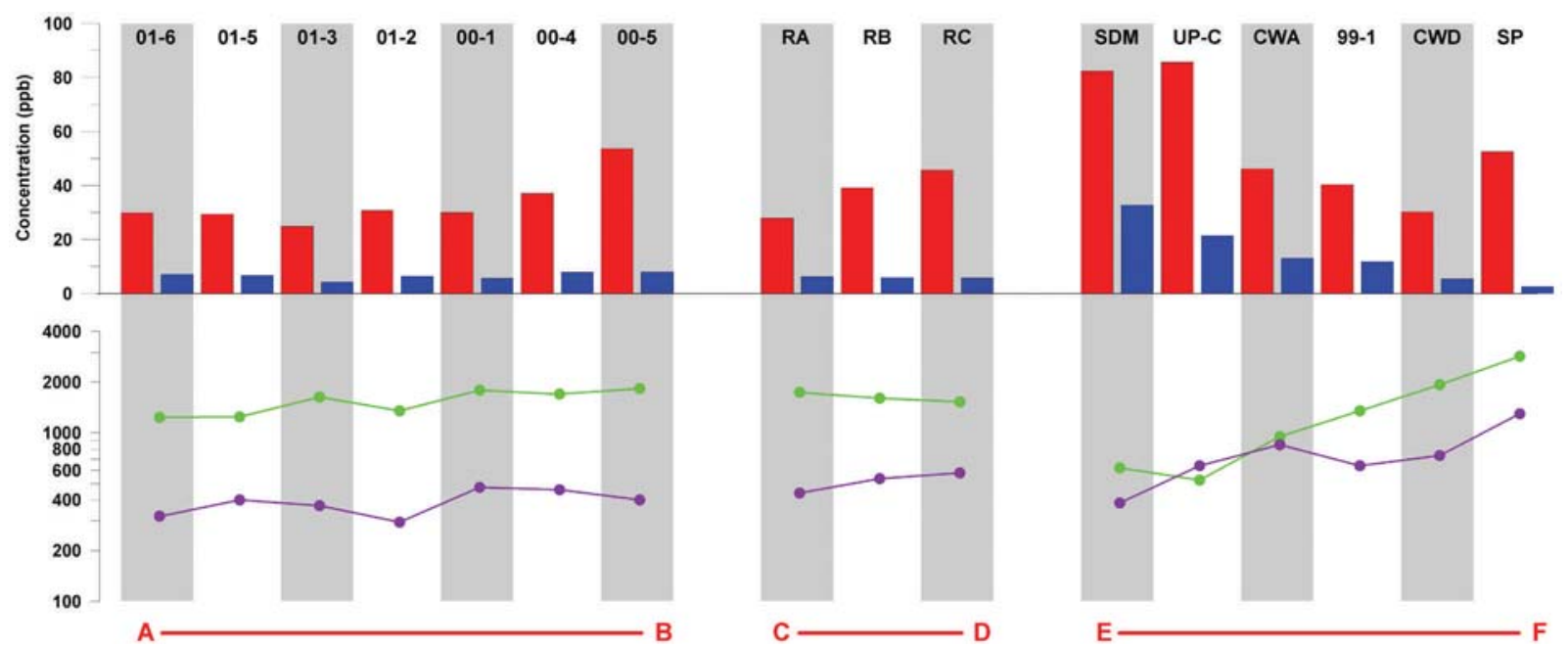

Fig. 2. Mean excess (red) and sea-salt (blue) sulfate concentrations in ppb for the years 1952-91 for each ice core used in this study. Green dots represent elevation in meters. Purple dots represent distance from nearest open water in kilometers. Red lines (A-B, C-D and E-F) are transects from Figure 1 (not to scale).

reached in one of the six ion concentrations. The ion that reaches zero concentration first is considered to be the conservative ion for that sample, and the concentration values for the other five ions are recorded. These become the excess (xs) concentrations for that sample. This technique is used in preference to the total- $\mathrm{Na}^{+}$conservative method because it takes all of the sea-salt ions into account when calculating sea-salt concentrations and therefore lessens the likelihood of a possible $\mathrm{ssSO}_{4}{ }^{2-}$ to $\mathrm{Na}^{+}$ratio bias caused by frost flower fractionation (Rankin and others, 2002). Previous research reveals no significant correlations between snow ion concentration and accumulation rate for Antarctic glaciochemical series in general (e.g. Mulvaney and Wolff, 1994; Kreutz and Mayewski, 1999; Kreutz and others, 2000a) or for the glaciochemical series used in this study (Dixon and others, 2004), so flux corrections for accumulation were not applied.

In order to characterize and compare the total $\mathrm{SsSO}_{4}{ }^{2-}$ and $\mathrm{xSSO}_{4}{ }^{2-}$ concentration at each ice-core site, we calculate mean values for the period 1952-91 (Fig. 2). We use 1952-91 because this is the longest time period for which we have a large number of continuous ice-core time series (mean value for site 01-6 is calculated from 1978-91, the full length of the record). Raw $\mathrm{ssSO}_{4}{ }^{2-}$ and $\mathrm{xsSO}_{4}{ }^{2-}$ time series for the last 200 years are plotted to determine the seasonal and longer-term variance in each of the ice-core $\mathrm{SO}_{4}{ }^{2-}$ records (Fig. 3 ).

Linear correlations of annually averaged $\mathrm{ssSO}_{4}{ }^{2-}$ and $\mathrm{xSSO}_{4}{ }^{2-}$ concentrations from each core vs SIE data from 1973 to 1996 (Jacka, 1983) are performed (the Up-C core is not used because of data gaps) to determine how SIE is related to $\mathrm{SO}_{4}{ }^{2-}$ concentrations at the South Pole and across West Antarctica. The annual $\mathrm{xsSO}_{4}{ }^{2-}$ concentration is calculated for each year from June to June (referred to as type A), and the annual $\mathrm{ssSO}_{4}{ }^{2-}$ concentration is calculated from January to January (type B), as these periods best cover the annual concentration peak in each $\mathrm{SO}_{4}{ }^{2-}$ time series. The SIE data were compiled from satellite-derived maps (US Navy and US National Oceanic and Atmospheric Administration Joint Ice Center) which by definition have the ice edge determined by a sea-ice concentration of $>15 \%$ (Jacka, 1983, and monthly updates). For each month
(January 1973-December 1996), a latitudinal position of the sea-ice edge is available for every $10^{\circ}$ of longitude (Simmonds and Jacka, 1995), yielding 36 separate time series. The only missing data are for August 1975 for all longitudes. The August average (1973-96) for each longitude series was substituted for these missing values. The SIE data are annually averaged from June to June (A) and from January to January (B), resulting in annual SIE records that span the time periods 1974-96 and 1973-96 respectively. Correlations are performed between the $\mathrm{xSSO}_{4}{ }^{2-}(\mathrm{A})$ and SIE (A) data and the $\mathrm{ssSO}_{4}{ }^{2-}$ (B) and $\mathrm{SIE}$ (B) data. Longitudinal SIE segments that correlate above $95 \%$ significance are plotted on polar stereographic maps of Antarctica (see Table 2 for corresponding $r$ values).

\section{RESULTS AND DISCUSSION 50 year mean concentrations}

Sites 01-6, 01-5, 01-3, 01-2, 00-1, 00-4 and 00-5 are located along transect A-B from eastern to central to western West Antarctica (Fig. 1). The sites increase in elevation from $\sim 1200 \mathrm{~m}$ to $\sim 1800 \mathrm{~m}$ from east to west. Mean $\mathrm{xsSO}_{4}{ }^{2-}$ concentrations along this transect display relatively uniform values from eastern to central West Antarctica, and an increase from central to western West Antarctica (Fig. 2). The increase in mean $\mathrm{xSSO}_{4}{ }^{2-}$ concentration towards the west is believed to be the result of increased downward flow of sulfate-laden air from the midupper atmosphere over the Executive Committee Mountain Range, inferred from atmospheric flow models in this area (Guo and others, 2003).

Ice-core sites RA, RB and RC are located in a $\sim 300 \mathrm{~km}$ northeast-southwest transect $(\mathrm{C}-\mathrm{D})$ descending from the ice divide into the Ross Ice Shelf catchment area (Fig. 1). Concentrations of $\mathrm{xSSO}_{4}{ }^{2-}$ along this transect exhibit an increasing trend toward site RC (Fig. 2), most likely as a consequence of closer proximity to the turbulent atmosphere over the Ross Ice Shelf area (Kreutz and Mayewski, 1999) and the biological productivity of the Ross Sea Polynya. Concentrations of $\mathrm{SsSO}_{4}{ }^{2-}$ remain relatively constant over the spread of sites 01-6, 0-5, 0-3, 0-2, 0-1, $0-4,0-5, R A, R B$ and RC. 


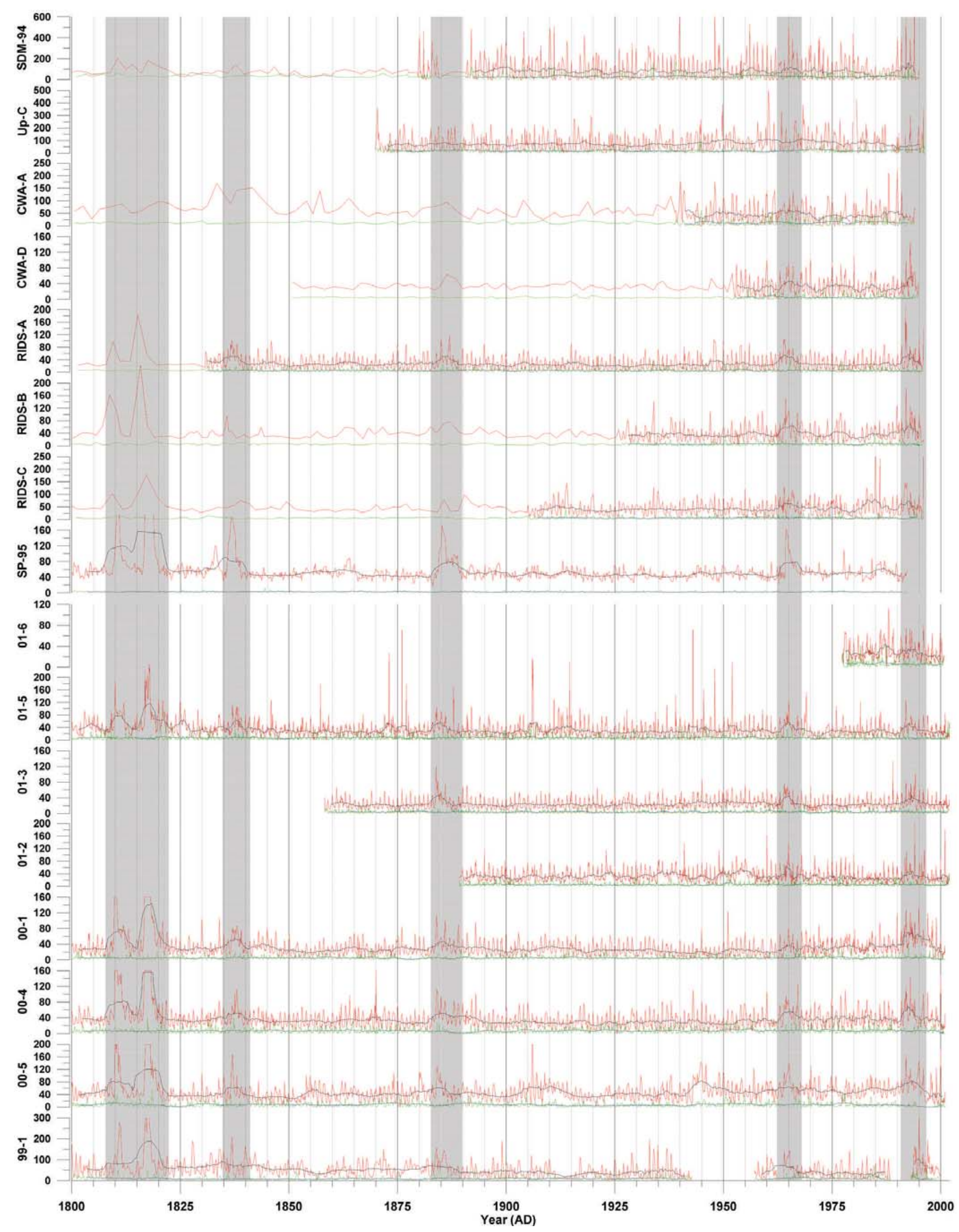

Fig. 3. Raw excess (red lines) and sea-salt (green lines) sulfate concentrations in ppb for the years 1800-2002 for each ice core used in this study. Black lines (excess) and blue lines (sea salt) represent 35- to 51-point running averages. Vertical lines represent 5 year increments. Shaded areas represent periods of increased $\mathrm{xsSO}_{4}{ }^{2-}$ input from known global-scale volcanic events. 
Table 2. Pearson's $r$ values for the 95\% and 99\% significance level in correlations between annually averaged sea-ice extent and annually averaged $\mathrm{xsSO}_{4}$ and $\mathrm{ssSO}_{4}$ concentrations

\begin{tabular}{|c|c|c|c|c|c|}
\hline $\mathrm{SsSO}_{4}-\mathrm{SIE}(\mathrm{B})$ correlation & $r=95 \%$ & $r=99 \%$ & $\mathrm{xsSO}_{4}-\mathrm{SIE}(\mathrm{A})$ correlation & $r=95 \%$ & $r=99 \%$ \\
\hline $01-6 \mathrm{ssSO}_{4}$ & 0.456 & 0.575 & $01-6 \mathrm{xsSO}_{4}$ & 0.456 & 0.575 \\
\hline $01-3 \mathrm{ssSO}_{4}$ & 0.405 & 0.516 & $01-3 \mathrm{xsSO}_{4}$ & 0.414 & 0.526 \\
\hline $01-2 \mathrm{ssSO}_{4}$ & 0.405 & 0.516 & $01-2 \mathrm{xsSO}_{4}$ & 0.414 & 0.526 \\
\hline 00-1 $\mathrm{ssSO}_{4}$ & 0.405 & 0.516 & $00-1 \mathrm{xsSO}_{4}$ & 0.414 & 0.526 \\
\hline $00-5 \mathrm{ssSO}_{4}$ & 0.405 & 0.516 & $00-5 \mathrm{xsSO}_{4}$ & 0.414 & 0.526 \\
\hline RIDS-A ssSO 4 & 0.414 & 0.526 & RIDS-A $x S_{4}$ & 0.423 & 0.537 \\
\hline RIDS-B ssSO 4 & 0.414 & 0.526 & RIDS-B $x S_{4}$ & 0.423 & 0.537 \\
\hline RIDS-C $\mathrm{ssSO}_{4}$ & 0.414 & 0.526 & RIDS-C $x S_{4}$ & 0.423 & 0.537 \\
\hline $\mathrm{SDM}_{-94} \mathrm{ssSO}_{4}$ & 0.423 & 0.537 & $\mathrm{SDM}_{-94} \mathrm{xsSO}_{4}$ & 0.433 & 0.549 \\
\hline $\mathrm{CWAA} \mathrm{SsSO}_{4}$ & 0.433 & 0.549 & 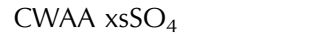 & 0.444 & 0.561 \\
\hline $99-1 \mathrm{ssSO}_{4}$ & 0.497 & 0.623 & 99-1 $\mathrm{xsSO}_{4}$ & 0.514 & 0.641 \\
\hline $\mathrm{CWAD} \mathrm{ssSO}_{4}$ & 0.433 & 0.549 & 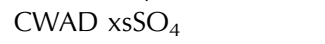 & 0.444 & 0.561 \\
\hline
\end{tabular}

Sites SDM-94, Up-C, CWA-A, 99-1, CWA-D and SP-95 lie on transect $\mathrm{E}-\mathrm{F}$ and range in elevation from $620 \mathrm{~m}$ at the edge of the Ross Ice Shelf to $2850 \mathrm{~m}$ at South Pole (Fig. 1). Concentrations of $\mathrm{xSSO}_{4}{ }^{2-}$ decrease with increasing elevation up to site CWA-D, and the trend reverses between CWA-D and SP-95 (Fig. 2) as a result of multiple input sources (tropospheric and stratospheric) for $\mathrm{xsSO}_{4}{ }^{2-}$ in this area (Proposito and others, 2002; Dixon and others, 2004). Concentrations of $\mathrm{ssSO}_{4}{ }^{2-}$ along the same transect decrease steadily toward South Pole with increasing elevation and distance from the coast, indicating a single lower-tropospheric source for marine ions that reach the polar plateau.

\section{Raw concentrations}

Plots of raw (unprocessed) $\mathrm{ssSO}_{4}{ }^{2-}$ and $\mathrm{xsSO}_{4}{ }^{2-}$ concentrations against time (Fig. 3) illustrate the large (more than an order of magnitude in some cases) increases in $\mathrm{xsSO}_{4}{ }^{2-}$ immediately following several global-scale large explosive volcanic eruptions (Tambora (1815), Cosiguina, Nicaragua (1835), Krakatau (1883), Agung (1963) and Pinatubo (1991)) in the sub-annually resolved data from all cores except SDM-94, Up-C and CWA-A (Dixon and others, 2004).

The majority of the West Antarctic ice-core sites in this study (01-6, 01-5, 01-3, 01-2, 00-1, 00-4, 99-1, RA, RB, RC, Up-C, CWA-A and CWA-D) have high annual $\mathrm{xsSO}_{4}{ }^{2-}$ variance, commonly displaying low winter $\mathrm{xsSO}_{4}{ }^{2-}$ concentrations in the 0-10 ppb range. Site 01-5 (Fig. 3) has high $\mathrm{xSSO}_{4}{ }^{2-}$ concentration variance and low winter $\mathrm{xsSO}_{4}{ }^{2-}$ concentrations, but it contains numerous large $\mathrm{xsSO}_{4}{ }^{2-}$ peaks that are not related to global-scale volcanic eruptions because they do not appear at any other site and do not correspond to historic global-scale volcanic events. The large peaks in 01-5 may be a result of local volcanism, biogenic $\mathrm{xsSO}_{4}{ }^{2-}$ input from nearby polynyas, or evaporite dust input from the nearby Ellsworth Mountains. The most likely cause for the majority of these large peaks is evaporite dust because of coincident large $\mathrm{Ca}^{2+}$ peaks.

Site SP-95 (Fig. 3) maintains a relatively high $\mathrm{xsSO}_{4}{ }^{2-}$ baseline ( $\sim 50 \mathrm{ppb})$ and low ( $\sim 30-70 \mathrm{ppb})$ variance throughout the year compared to other sites. It also contains unusually large (sometimes more than an order of magnitude above the mean) $\mathrm{xsSO}_{4}{ }^{2-}$ signatures from global-scale volcanic eruptions. The SP-95 $\mathrm{xsSO}_{4}{ }^{2-}$ volcanic signatures are a result of its high $(\sim 2850 \mathrm{~m})$ elevation and direct access to upper-tropospheric/stratospheric air masses (Dixon and others, 2004).

Non-volcanic $\mathrm{xSSO}_{4}{ }^{2-}$ concentrations at site 00-5 (Fig. 3) are similar in structure to those at SP-95 (high background, low variance) during several short periods over the last 200 years (e.g. 1942-47, 1908-13) but are similar to the majority of West Antarctic sites for the remainder of the record (low winter values, high variance). The change in $\mathrm{xsSO}_{4}{ }^{2-}$ deposition style at site 00-5 may reflect changes in the strength of downward airflow over the Executive Committee Range (as discussed earlier). Periods of strengthened downward flow may cause the $\mathrm{xSSO}_{4}{ }^{2-}$ signature at site 00-5 to be more similar to that at SP-95.

The mean $\mathrm{xSSO}_{4}{ }^{2-}$ concentrations at SDM-94 (Fig. 3) frequently decrease to $\sim 30 \mathrm{ppb}$, comparable to, or lower than, the mean $\mathrm{SsSO}_{4}{ }^{2-}$ concentration at that site, suggesting a high event frequency of at least one of the major $\mathrm{xsSO}_{4}{ }^{2-}$ sources to the site, probably marine biogenic $\mathrm{xsSO}_{4}{ }^{2-}$. The low elevation and proximity to the coast of the SDM-94 site signify that its major $\mathrm{SO}_{4}{ }^{2-}$ sources are sea salt and marine biological productivity from the adjacent ocean area. Therefore, a likely cause for the observed $\mathrm{xsSO}_{4}{ }^{2-}$ fluctuations is variability of Ross Sea climatic conditions. Interestingly, the $\mathrm{xSSO}_{4}{ }^{2-}$ fluctuations in the SDM-94 record are not observed at Up-C or CWA-A as would be expected from events of this magnitude. Another reason for the independent behavior of SDM-94 $\mathrm{xSSO}_{4}{ }^{2-}$ concentrations may be the location of the site. The SDM-94 core site is located on the top of a $600 \mathrm{~m}$ high dome; this protruding geography may prevent certain air masses from reaching the ice-core drill site and could well be a factor regarding the unique character of the glaciochemical concentrations.

Almost every core in this study has a mean $\mathrm{ssSO}_{4}{ }^{2-}$ to $\mathrm{xsSO}_{4}{ }^{2-}$ ratio between 0.13 and 0.29 (Table 1 ); the exceptions are SP-95 with a ratio of 0.05, and SDM-94 with a ratio of 0.40 . The low ratio at SP-95 is caused by a combination of extremely low $\mathrm{SsSO}_{4}{ }^{2-}$ concentrations resulting from its high elevation and distance from the coast, and the fact that $\mathrm{xsSO}_{4}{ }^{2-}$ concentrations at this site maintain a relatively constant baseline $(\sim 50 \mathrm{ppb})$ and low 


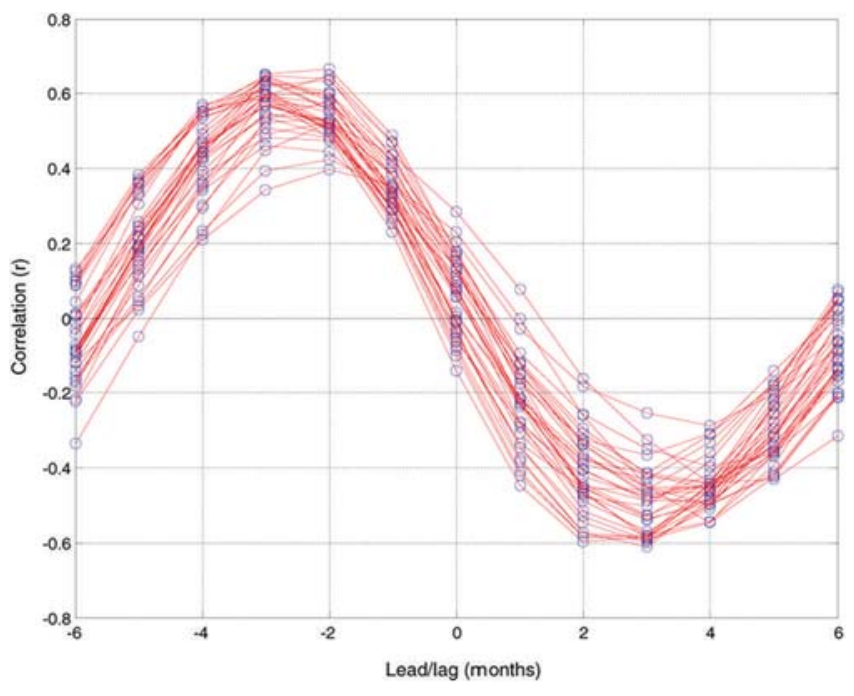

Fig. 4. Correlation results for SDM-94 monthly excess sulfate concentrations against every $10^{\circ}$ monthly sea-ice data segment from 0 to $360^{\circ}$ longitude.

( $\sim 30-70 \mathrm{ppb})$ variance throughout the year. The high $\mathrm{SsSO}_{4}{ }^{2-}$ to $\mathrm{xsSO}_{4}{ }^{2-}$ ratio at SDM-94 is a result of extremely high $\mathrm{SSSO}_{4}{ }^{2-}$ concentrations resulting from proximity to the Ross Ice Shelf edge and Ross Sea Polynya.

\section{Sea-ice correlations}

Linear correlation between monthly values of SIE and monthly values of SDM-94 $\mathrm{xsSO}_{4}{ }^{2-}$ (from 1973-94) was performed to determine if SIE exhibited any significant associations with $\mathrm{xSSO}_{4}{ }^{2-}$ concentrations in precipitation (Fig. 4). We chose SDM-94 to begin with because it is the nearest to open water of our low-elevation sites. The monthly values were calculated by resampling the original time series to 12 samples per year based on the assumption that the annual $\mathrm{xsSO}_{4}{ }^{2-}$ peak occurs near the December/ January transition (Minikin and others, 1998). The results show that the strongest correlations are obtained when records are lead/lagged $2-3$ months. This is because the maximum and minimum SIE occurs in September/October and March/April respectively and the $\mathrm{xsSO}_{4}{ }^{2-}$ peak falls on the December/January transition. To overcome any further possible autocorrelation problems, we resampled both time series to annual resolution. The results for SDM-94 $\mathrm{xsSO}_{4}{ }^{2-}$ and SIE reveal that the most robust correlation $(r>0.6>99 \%$ significance) occurs with no leads or lags. Figure 5 shows that the strongest correlations occur with SIE from longitudes $70-80^{\circ}, 130-150^{\circ}$ and $200-240^{\circ}$.

Linear correlations with annually averaged SIE from 1973-96 were also performed on the annually averaged $\mathrm{xsSO}_{4}{ }^{2-}$ and $\mathrm{ssSO}_{4}{ }^{2-}$ records from each core (Figs 6 and 7) for the full period of data overlap. With SIE calculated as a function of latitude in Figures 6 and 7, a positive correlation means decreased SIE when $\mathrm{SO}_{4}{ }^{2-}$ concentrations are high, and a negative correlation means increased $\mathrm{SIE}$ when $\mathrm{SO}_{4}{ }^{2-}$ concentrations are high. The statistically significant (>95\%) results show that in general the SIE closest to West Antarctic ice-core sites, in the Ross, Amundsen and Bellingshausen Seas, is negatively correlated with $\mathrm{SsSO}_{4}{ }^{2-}(r \geq 0.405-0.537)$ and positively correlated with $\mathrm{xSSO}_{4}{ }^{2-}(r \geq 0.414-0.561)$ concentrations.

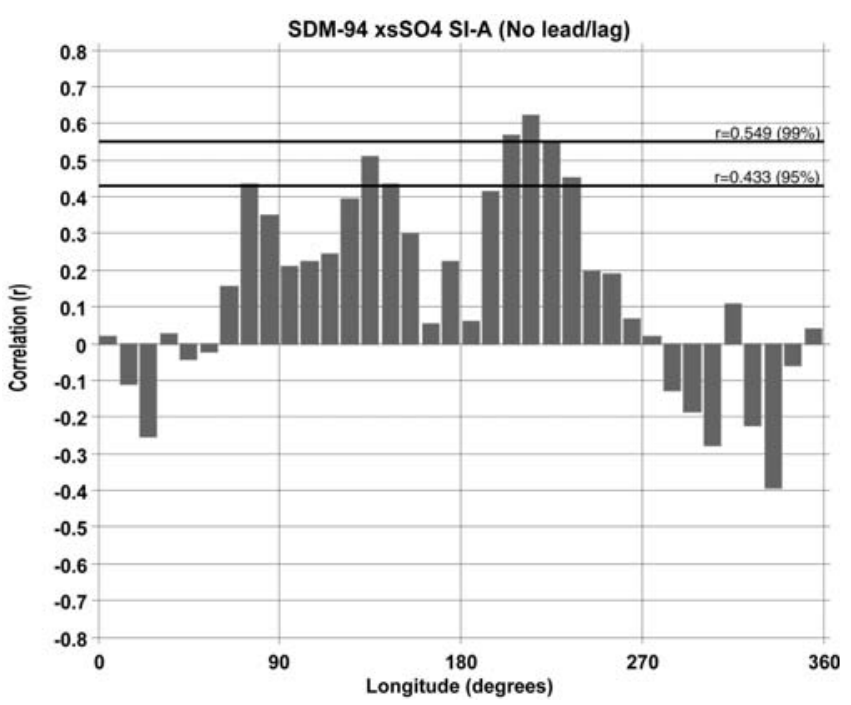

Fig. 5. Correlation results for SDM-94 annual excess sulfate concentrations against every $10^{\circ}$ annual sea-ice extent data segment from 0 to $360^{\circ}$ longitude. $(N=22 ; r \geq 0.433=95 \%$ significant; $r \geq 0.549=99 \%$ significant.)

West Antarctic ice-core sites (SDM-94, 00-1, 00-4, 01-3 and RIDS-A) exhibit increased concentrations of $\mathrm{xsSO}_{4}{ }^{2-}$ when SIE in the Bellingshausen-Amundsen-Ross (Pacific) region is reduced (Fig. 6). At the same time, when $\mathrm{xSSO}_{4}{ }^{2-}$ concentrations at site 01-3 are higher, the SIE in the Pacific region is reduced and the SIE in the Weddell (Atlantic) region is increased. If the primary $\mathrm{xSSO}_{4}{ }^{2-}$ source for site 01-3 is the Weddell region, our result is in agreement with several previous studies (Welch and others, 1993; Meyerson and others, 2002; Curran and others, 2003); but if, as is more likely, the primary $\mathrm{xsSO}_{4}{ }^{2-}$ source for site $01-3$ is the Bellingshausen-Amundsen-Ross region, our results suggest that the $\mathrm{SIE}-\mathrm{xsSO}_{4}{ }^{2-}$ relationship is opposite to that of SIE-MS. The associations present in the Weddell region may be related to the Antarctic dipole, which manifests itself as out-of-phase retreat (advance) of sea ice in the Atlantic (Pacific) ocean basins (Yuan and Martinson, 2000). Assuming the latter to be true, differences between our results and those of previous studies (Welch and others, 1993; Curran and others, 2003) may be due to the fact that none of our sites are truly coastal locations (although SDM-94 has some coastal characteristics). Also, we examine $\mathrm{xsSO}_{4}{ }^{2-}$ concentrations rather than MS, and the ice-core locations for all previous studies are in East Antarctica.

Linear correlation between $\mathrm{SsSO}_{4}{ }^{2-}$ and SIE (Fig. 7) reveals that concentrations of $\mathrm{SsSO}_{4}{ }^{2-}$ are higher at several West Antarctic sites (CWA-A, 00-1, 00-4, 00-5, RIDS-A, RIDS-B and CWA-D) when there is greater SIE in the Amundsen, Ross and Bellingshausen Seas. There could be several possible mechanisms for this association. One is increased sea-ice production leading to greater frost flower growth and resulting in greater volumes of highly saline aerosols (Rankin and others, 2002; Kaspari and others, 2005). Another is increased meridional transport and higher wind speeds over the open-ocean surface during colder years, causing greater concentrations of ss aerosols to reach the ice sheet (Curran and others, 1998; Kreutz and others, 2000b). The most likely explanation is that both of these mechanisms are responsible to varying degrees for the observed relationship between $\mathrm{SsSO}_{4}{ }^{2-}$ and SIE. 


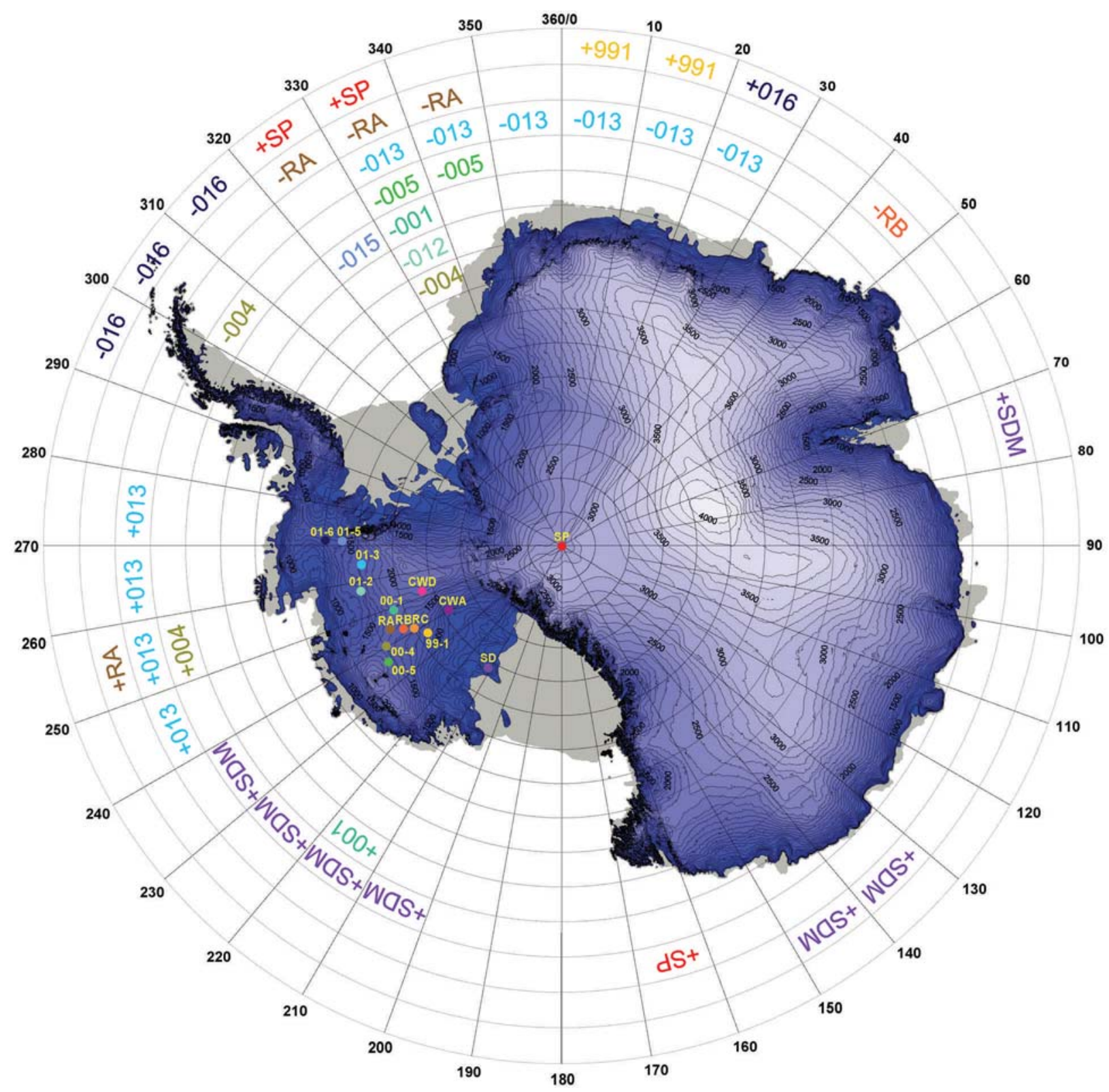

Fig. 6. Correlations between annually averaged sea-ice extent and excess sulfate. All plotted sites represent correlations above $95 \%$ significance. $\mathrm{A}^{\prime}+{ }^{\prime}$ indicates a positive correlation and $\mathrm{a}{ }^{\prime}-{ }^{\prime}$ indicates a negative correlation for each associated ice-core site. Latitudinal position of text has no significance. RA, RB and RC represent core sites RIDS-A, RIDS-B and RIDS-C, respectively. SD, CWA, CWD and SP represent SDM-94, CWA-A, CWA-D and SP-95 respectively. Map created using the RAMP digital elevation model (Liu and others, 2001).

Our study of $\mathrm{xsSO}_{4}{ }^{2-}$ does not reveal strong associations between longitudinal bands of SIE in the Amundsen-Ross region and $\mathrm{SP}-95 \mathrm{xSSO}_{4}{ }^{2-}$ concentrations, but it does show a positive association between increased $\mathrm{SP}_{-95} \mathrm{xsSO}_{4}{ }^{2-}$ concentrations and reduced SIE in the Weddell Sea region. The SP-95 SIE correlation of Meyerson and others (2002) is based upon smoothed (seven-point running mean) monthly MS and SIE values and an average SIE calculated from $185^{\circ}$ to $245^{\circ}$ longitude; this may explain why we do not see similar correlation patterns in our study. The positive association we observe between increased SP-95 $\mathrm{xsSO}_{4}{ }^{2-}$ concentrations and reduced SIE in the Weddell Sea region suggests that the source region for $\mathrm{SP}-95 \mathrm{xsSO}_{4}{ }^{2-}$ is probably different to that of the West Antarctic cores in this study.

An important consideration on the sulfur budget of West Antarctica is the effect of coastal polynyas. Three of the four most productive Antarctic polynyas surround West Antarctica, and the dominant polynya with respect to total area-weighted production is in the Ross Sea, accounting for half of the total polynya production on the entire Antarctic continental shelf (Arrigo and Van Dijken, 2003). The peak production in January averaged over all polynya waters is more than three times higher than the average for the entire offshore Southern Ocean (Arrigo and Van Dijken, 2003). As a result, polynyas may be a significant source of both $\mathrm{SsSO}_{4}{ }^{2-}$ (in winter) and $\mathrm{xSSO}_{4}{ }^{2-}$ (in summer) to West Antarctic sites.

\section{Background sulfate concentrations}

There are no significant trends apparent in the robust splinesmoothed $\mathrm{ssSO}_{4}{ }^{2-}$ concentrations over the last 200 years (Fig. 8). In a previous study (Dixon and others, 2004) we showed that a significant rise in background $\mathrm{xsSO}_{4}{ }^{2-}$ 


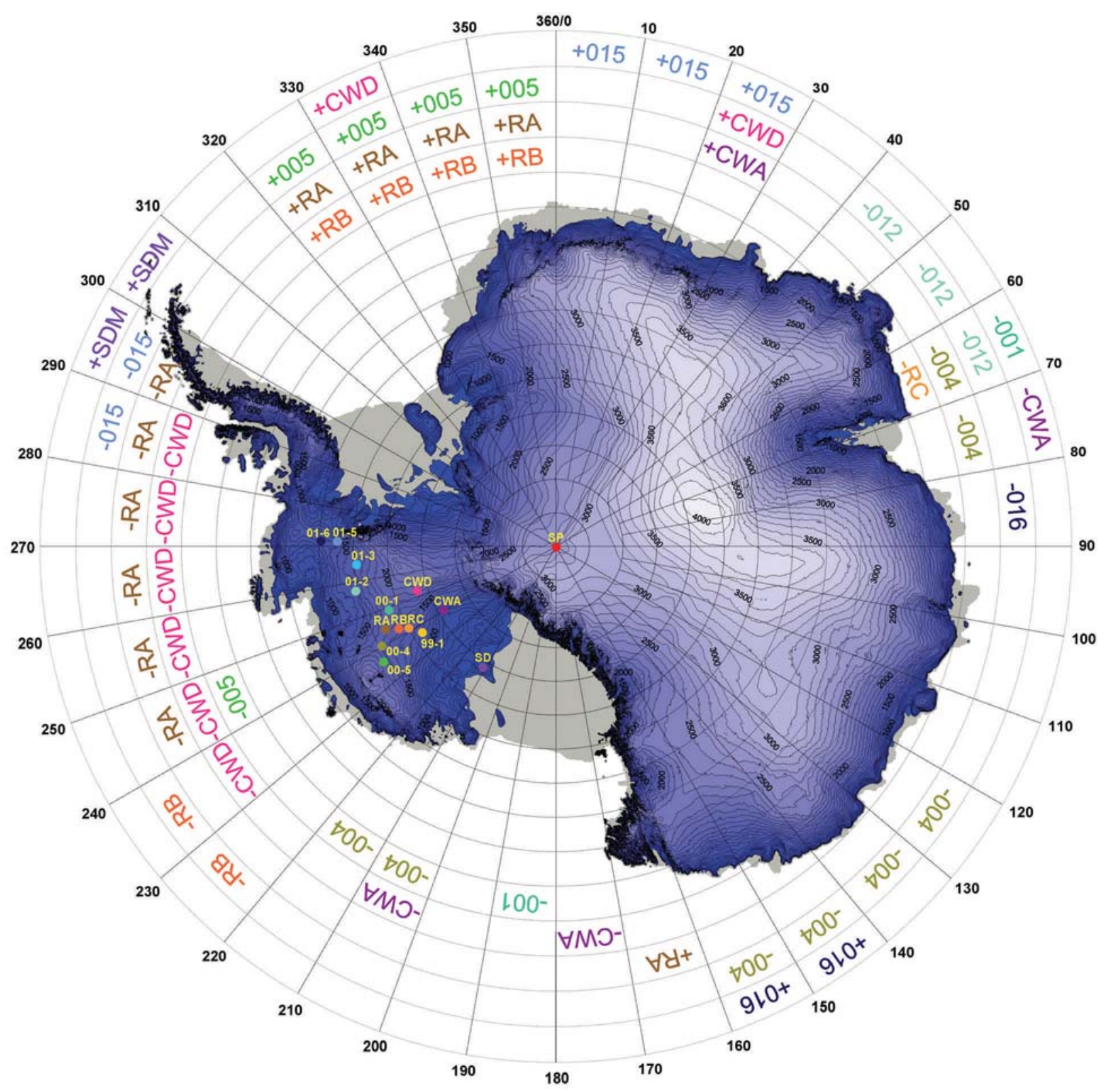

Fig. 7. Correlations between annually averaged sea-ice extent and sea-salt sulfate. For details see Figure 6 caption.

concentrations occurs from 1940 to the present at central West Antarctic ice-core sites (00-1, 00-4, 00-5, RIDS-A, RIDS-B and RIDS-C; Fig. 8). We argued that the rise could not be attributed to anthropogenic activities since it does not show up in all our high-elevation $\mathrm{xsSO}_{4}{ }^{2-}$ concentration records. Here we suggest that the $1940 \mathrm{xsSO}_{4}{ }^{2-}$ rise cannot be attributed to changes in sea-ice extent since $\mathrm{xsSO}_{4}{ }^{2-}$ concentrations at sites 00-5, RIDS-B and RIDS-C are not statistically related to SIE (in the Ross, Amundsen and Bellingshausen Seas) above 95\% significance, and sites 00-1, 00-4 and RIDS-A are not related to SIE (in the Ross, Amundsen and Bellingshausen Seas) above 99\% significance. Figures 6 and 7 show that the core sites displaying the strongest $\mathrm{xsSO}_{4}{ }^{2-}$ association with SIE are SDM-94 and 01-3; conversely sites 00-4, RIDS-A and CWA-D display the strongest $\mathrm{ssSO}_{4}{ }^{2-}$ association with SIE. This suggests that central West Antarctica is not significantly affected by lowertropospheric coastal air masses during the summer months but is significantly affected by these air masses during the winter period.
A study by Kaspari and others (2004) shows that central West Antarctic precipitation is statistically linked to the midlow latitudes. This may suggest that the 1940 rise in $\mathrm{xsSO}_{4}{ }^{2-}$ is related to a change in production in the mid-low latitudes and/or increased transport from the mid-low latitudes to central West Antarctica.

\section{CONCLUSIONS}

In this study, we present the $\mathrm{ssSO}_{4}{ }^{2-}$ and $\mathrm{xsSO}_{4}{ }^{2-}$ records from 16 sub-annually resolved ice cores from West Antarctica. There are several sources and transport pathways of $\mathrm{SsSO}_{4}{ }^{2-}$ and $\mathrm{xsSO}_{4}{ }^{2-}$ and these vary from site to site and can only be resolved from a multiple core study.

Linear correlations between SIE and the $\mathrm{SsSO}_{4}{ }^{2-}$ and $\mathrm{xsSO}_{4}{ }^{2-}$ records from 15 of the cores in this study reveal that for several sites $\mathrm{SSSO}_{4}{ }^{2-}$ concentrations are higher with increased $\mathrm{SIE}$, and $\mathrm{xSSO}_{4}{ }^{2-}$ concentrations are higher when SIE is decreased. It is important to note that although our results demonstrate a strong association between SIE and 

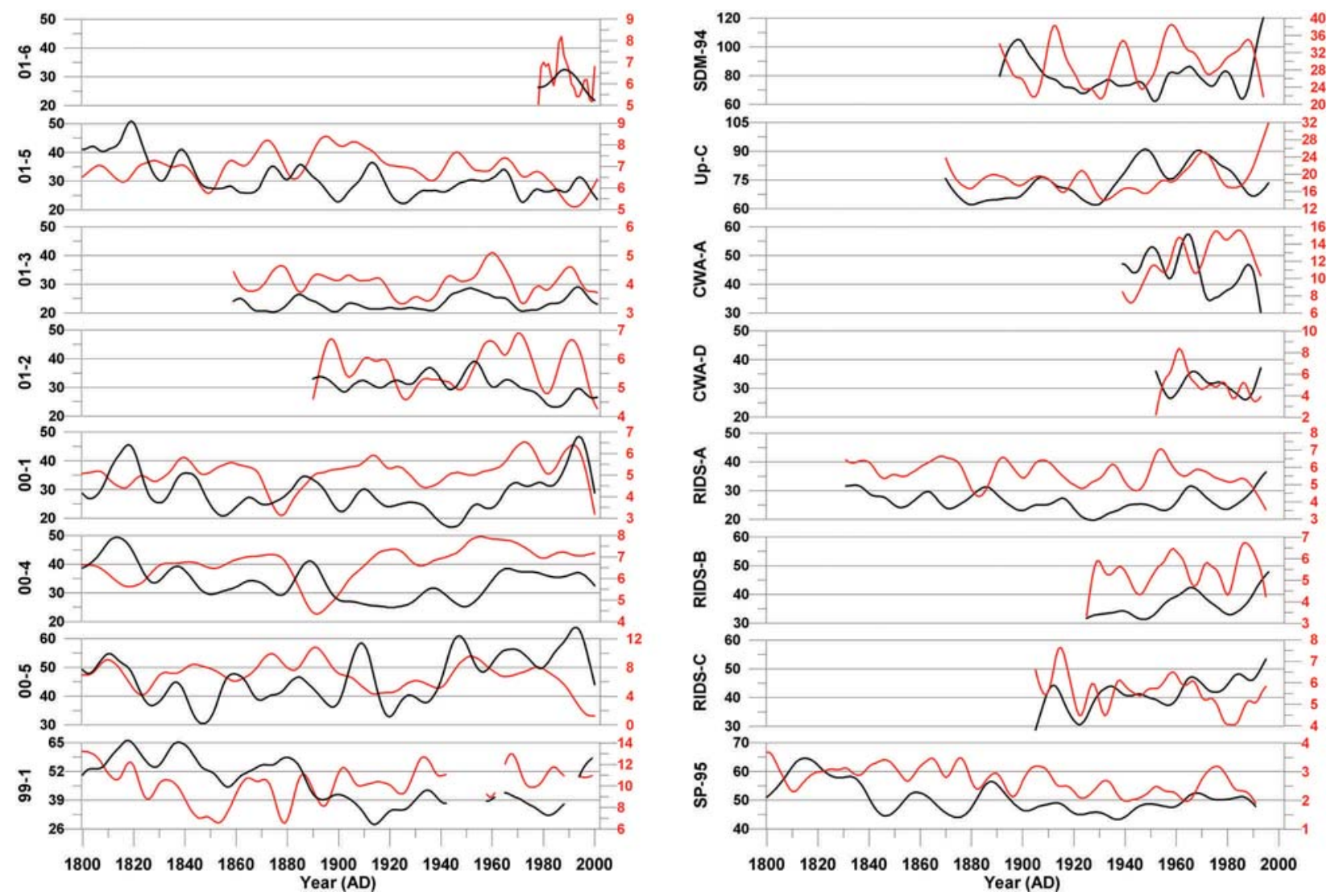

Fig. 8. Robust spline-smoothed annual excess sulfate (black) and sea-salt sulfate (red) concentrations for each ice core for the years $1800-$ 2002. All concentrations are in ppb. Note scale change from site to site.

$\mathrm{SO}_{4}{ }^{2-}$ concentrations in West Antarctica, they do not necessarily imply direct causal links. The two parameters (SIE and $\mathrm{SO}_{4}{ }^{2-}$ ) may be teleconnected to a third parameter that forces both simultaneously. Our SIE- $\mathrm{SSSO}_{4}{ }^{2-}$ association supports the concept that frost flower growth on sea ice may be an important source of $\mathrm{SsSO}_{4}{ }^{2-}$ aerosol to inland West Antarctic sites as noted by Rankin and others (2002) and Kaspari and others (2005). Conversely, our SIE$\mathrm{xSSO}_{4}{ }^{2-}$ association suggests that during periods of decreased SIE in the Bellingshausen-Amundsen-Ross region, more $\mathrm{xsSO}_{4}{ }^{2-}$ is deposited in West Antarctica. This latter result does not agree with the results of previous studies that find a positive association between elevated MS concentrations and increased SIE (Welch and others, 1993; Curran and others, 2003) but it is consistent with the observations of Peel and others (1996) who find that extensive sea-ice cover tends to suppress emissions of DMS. The association between SIE and SP-95 $\mathrm{xsSO}_{4}{ }^{2-}$ in this study shows that the $\mathrm{SP}-95$ site receives more $\mathrm{xsSO}_{4}{ }^{2-}$ when SIE in the Weddell region is decreased, the opposite relationship to our West Antarctic sites that receive more $\mathrm{xsSO}_{4}{ }^{2-}$ when SIE in the Bellingshausen-Amundsen-Ross region is decreased.

The out-of-phase behavior between SIE in the Weddell region and the rest of Antarctica is a common pattern for Southern Ocean sea ice and is evident in our SIE- $-\mathrm{SO}_{4}{ }^{2-}$ associations. It is most likely related to the structure of the Antarctic dipole (Yuan and Martinson, 2001) and it highlights the strong links between Antarctic climate and the climate of the tropical and mid-latitude Southern Hemisphere. Yuan and Martinson (2000) found consistent and statistically significant teleconnection patterns linking Antarctic SIE variations (including an out-of-phase relationship between Pacific and Atlantic polar regions) to those of mid- and low-latitude climate that are verified by our study.

The 1940 rise in $\mathrm{xsSO}_{4}{ }^{2-}$ background concentrations in our central West Antarctic ice cores cannot be attributed to changes in SIE. The most likely explanation for this trend is an increase in $\mathrm{xSSO}_{4}{ }^{2-}$ production in the mid-low latitudes around 1940 and/or an increase in transport efficiency from the mid-low latitudes to central West Antarctica at that time.

The influence of coastal polynyas on the West Antarctic $\mathrm{SO}_{4}{ }^{2-}$ budget is of utmost importance to the understanding and interpretation of ice-core records. Future work should focus on the associations between summer and winter polynya activity and the $\mathrm{ssSO}_{4}{ }^{2-}$ and $\mathrm{xsSO}_{4}{ }^{2-}$ time series in ice cores, particularly from western West Antarctica.

\section{REFERENCES}

Arrigo, K.R. and G.L. van Dijken. 2003. Phytoplankton dynamics within 37 Antarctic coastal polynya systems. J. Geophys. Res., 108(C8), 3271. (10.1029/2002JC001739.)

Arrigo, K.R., D. Worthen, A. Schnell and M.P. Lizotte. 1998. Primary production in Southern Ocean waters. J. Geophys. Res., 103(C8), 15,587-15,600.

Bates, T.S., B.K. Lamb, A. Guenther, J. Dignon and R.E. Stoiber. 1992. Sulfur emissions to the atmosphere from natural sources. J. Atmos. Chem., 14(1-4), 315-337.

Bergin, M.H., E.A. Meyerson, J.E. Dibb and P.A. Mayewski. 1998. Relationship between continuous aerosol measurements and 
firn core chemistry over a 10-year period at the South Pole. Geophys. Res. Lett., 25(8), 1189-1192.

Berresheim, H., P.H. Wine and D.D. Davis. 1995. Sulfur in the atmosphere. In Singh, H.B., ed. Composition, chemistry and climate of the atmosphere. New York, Van Nostrand Reinhold, 251-307.

Bromwich, D.H., J.F. Carrasco and C.R. Stearns. 1992. Satellite observations of katabatic wind propagation for great distances across the Ross Ice Shelf. Mon. Weather Rev., 120(9), 1940-1949.

Buck, C.F., P.A. Mayewski, M.J. Spencer, S. Whitlow, M.S. Twickler and D. Barrett. 1992. Determination of major ions in snow and ice cores by ion chromatography. J. Chromatogr., 594(1-2), 225-228.

Carleton, A.M. 1992. Synoptic interactions between Antarctica and lower latitudes. Aust. Met. Mag., 40(3), 129-147.

Charlson, R.J., J. Langner and H. Rohde. 1990. Sulfate aerosol and climate. Nature, 348(6296), 22.

Cullather, R.I., D.H. Bromwich and M.L. van Woert. 1996. Interannual variations in Antarctic precipitation related to ElNiño-Southern Oscillation. J. Geophys. Res., 101(D14), 19,109-19,118.

Curran, M.A.J., T.D. van Ommen and V. Morgan. 1998. Seasonal characteristics of the major ions in the high-accumulation Dome Summit South ice core, Law Dome, Antarctica. Ann. Glaciol., 27, 385-390.

Curran, M.A.J., T.D. van Ommen, V.I. Morgan, K.L. Phillips and A.S. Palmer. 2003. Ice core evidence for Antarctic sea ice decline since the 1950s. Science, 302(5648), 1203-1206.

Dibb, J.E. and S.I. Whitlow. 1996. Recent climatic anomalies and their impact on snow chemistry at South Pole, 1987-1994. Geophys. Res. Lett., 23(10), 1115-1118.

Dixon, D., P.A. Mayewski, S. Kaspari, S. Sneed and M. Handley. 2004. A 200-year sub-annual record of sulfate in West Antarctica from 16 ice cores. Ann. Glaciol., 39, 545-556.

Guo, Z., D.H. Bromwich and J.J. Cassano. 2003. Evaluation of Polar MM5 simulations of Antarctic atmospheric circulation. Mon. Weather Rev., 131, 384-411.

Hogan, A. 1997. A synthesis of warm air advection to the South Polar Plateau. J. Geophys. Res., 102(D12), 14,009-14,020.

Holland, H.D. 1978. The chemistry of the atmosphere and oceans. New York, Wiley-Interscience.

Jacka, T.H. 1983. A computer data base for Antarctic sea ice extent. ANARE Research Notes 13.

Jouzel, J., L. Merlivat, J.R. Petit and C. Lorius. 1983. Climatic information over the last century deduced from a detailed isotopic record in the South Pole snow. J. Geophys. Res., 88(C4), 2693-2703.

Kaspari, S. and 6 others. 2004. Climate variability in West Antarctica derived from annual accumulation rate records from ITASE firn/ice cores. Ann. Glaciol., 39, 585-594.

Kaspari, S., P.A. Mayewski, D.A. Dixon, S.B. Sneed and M.J. Handley. 2005. Sources and transport pathways of marine aerosol species into West Antarctica. Ann. Glaciol., 41 (see paper in this volume).

Kreutz, K.J. and P.A. Mayewski. 1999. Spatial variability of Antarctic surface snow glaciochemistry: implications for paleoatmospheric circulation reconstructions. Antarct. Sci., 11(1), 105-118.

Kreutz, K.J., P.A. Mayewski, L.D. Meeker, M.S. Twickler, S.I. Whitlow and I.I. Pittalwala. 1997. Bipolar changes in atmospheric circulation during the Little Ice Age. Science, 277(5330), 1294-1296.

Kreutz, K.J., P.A. Mayewski, L.D. Meeker, M.S. Twickler and S.I. Whitlow. 2000a. The effect of spatial and temporal accumulation rate variability in West Antarctica on soluble ion deposition. Geophys. Res. Lett., 27(16), 2517-2520.

Kreutz, K.J., P.A. Mayewski, I.I. Pittalwala, L.D. Meeker, M.S. Twickler and S.I. Whitlow. 2000b. Sea level pressure variability in the Amundsen Sea region inferred from a West Antarctic glaciochemical record. J. Geophys. Res., 105(D3), 4047-4059.
Legrand, M. 1997. Ice-core records of atmospheric sulfur. Philos. Trans. R. Soc. London, Ser. B, 352(1350), 241-250.

Legrand, M. and R.J. Delmas. 1987. A 220-year continuous record of volcanic $\mathrm{H}_{2} \mathrm{SO}_{4}$ in the Antarctic ice sheet. Nature, 327(6124), 671-676.

Legrand, M. and P. Mayewski. 1997. Glaciochemistry of polar ice cores: a review. Rev. Geophys., 35(3), 219-243.

Legrand, M. and D. Wagenbach. 1999. Impact of the Cerro Hudson and Pinatubo volcanic eruptions on the Antarctic air and snow chemistry. J. Geophys. Res., 104(D1), 1581-1596.

Legrand, M., C. Feniet-Saigne, E.S. Saltzman and C. Germain. 1992. Spatial and temporal variations of methanesulfonic acid and non sea salt sulfate in Antarctic ice. J. Atmos. Chem., 14(1-4), 245-260.

Liu, H., K.C. Jezek, B. Li and Z. Zhao. 2001. RADARSAT Antarctic Mapping Project digital elevation model. Version 2. Boulder, CO, National Snow and Ice Data Center.

Mayewski, P.A. and 11 others. 1995. An ice-core-based, Late Holocene history for the Transantarctic Mountains, Antarctica. In Elliot, D.H. and G.L. Blaisdell, eds. Contributions to Antarctic research IV. Washington, DC, American Geophysical Union, 33-45. (Antarctic Research Series 67.)

Mayewski, P.A. and 10 others. 2004. A 700 year record of Southern Hemisphere extratropical climate variability. Ann. Glaciol., 39, 127-132.

Meyerson, E.A., P.A. Mayewski, K.J. Kreutz, L.D. Meeker, S.I. Whitlow and M.S. Twickler. 2002. The polar expression of ENSO and sea-ice variability as recorded in a South Pole ice core. Ann. Glaciol., 35, 430-436.

Minikin, A. and 7 others. 1998. Sulfur-containing species (sulfate and methanesulfonate) in coastal Antarctic aerosol and precipitation. J. Geophys. Res., 103(D9), 10,975-10,990.

Mulvaney, R. and D.A. Peel. 1988. Anions and cations in ice cores from Dolleman Island and the Palmer Land plateau, Antarctic Peninsula. Ann. Glaciol., 10, 121-125.

Mulvaney, R. and E.W. Wolff. 1994. Spatial variability of the major chemistry of the Antarctic ice sheet. Ann. Glaciol., 20, 440-447.

O'Brien, S.R., P.A. Mayewski, L.D. Meeker, D.A. Meese, M.S. Twickler and S.I. Whitlow. 1995. Complexity of Holocene climate as reconstructed from a Greenland ice core. Science, 270(5244), 1962-1964.

Peel, D.A., R. Mulvaney, E.C. Pasteur and C. Chenery. 1996. Climate changes in the Atlantic sector of Antarctica over the past 500 years from ice-core and other evidence. In Jones, P.D., R.S. Bradley and J. Jouzel, eds. Climatic variations and forcing mechanisms of the last 2000 years. Berlin, etc., SpringerVerlag, 243-262. (NATO ASI Series I: Global Environmental Change 41.)

Proposito, M. and 9 others. 2002. Chemical and isotopic snow variability along the 1998 ITASE traverse from Terra Nova Bay to Dome C, East Antarctica. Ann. Glaciol., 35, 187-194.

Rankin, A.M., V. Auld and E.W. Wolff. 2000. Frost flowers as a source of fractionated sea salt aerosol in the polar regions. Geophys. Res. Lett., 27(21), 3469-3472.

Rankin, A.M., E.W. Wolff and S. Martin. 2002. Frost flowers: implications for tropospheric chemistry and ice core interpretation. J. Geophys. Res., 107(D23), 4683. (10.1029/ 2002JD002492.)

Richardson, C. 1976. Phase relationships in sea ice as a function of temperature. J. Glaciol., 17(77), 507-519.

Shaw, G.E. 1982. On the residence time of the Antarctic ice sheet sulfate aerosol. J. Geophys. Res., 87(C6), 4309-4313.

Simmonds, I. and T.H. Jacka. 1995. Relationships between the interannual variability of Antarctic sea ice and the Southern Oscillation. J. Climate, 8(3), 637-647.

Wagenbach, D. 1996. Coastal Antarctica: atmospheric chemical composition and atmospheric transport. In Wolff, E.W. and R.C. Bales, eds. Chemical exchange between the atmosphere and polar snow. Berlin, etc., Springer-Verlag, 173-199. (NATO ASI Series I: Global Environmental Change 43.) 
Wagenbach, D. and 7 others. 1998. Sea-salt aerosol in coastal Antarctic regions. J. Geophys. Res., 103(D9), 10,961-10,974.

Welch, K.A., P.A. Mayewski and S.I. Whitlow. 1993. Methanesulfonic acid in coastal Antarctic snow related to sea ice extent. Geophys. Res. Lett., 20(6), 443-446.

Whitlow, S., P.A. Mayewski and J.E. Dibb. 1992. A comparison of major chemical species seasonal concentration and accumulation at the South Pole and Summit, Greenland. Atmos. Environ., 26A(11), 2045-2054.

Yuan, X. and D.G. Martinson. 2000. Antarctic sea ice extent variability and its global connectivity. J. Climate, 13(10), 16971717.

Yuan, X. and D.G. Martinson. 2001. The Antarctic dipole and its predictability. Geophys. Res. Lett., 28(18), 3609-3612. 